\title{
Contrasting temperature responses of dissolved organic carbon and phenols leached from soils
}

\author{
Jonathan S. Williams • Jennifer A. J. Dungait • \\ Roland Bol • Geoffrey D. Abbott
}

Received: 22 May 2015 / Accepted: 13 September 2015 / Published online: 23 September 2015

(C) The Author(s) 2015. This article is published with open access at Springerlink.com

\begin{abstract}
Background and aims Plant-derived phenols are a major input to the terrestrial carbon cycle that might be expected to contribute substantially to dissolved organic carbon (DOC) losses from soils. This study investigated changes in DOC and phenols in leachates from soil treated with individual plant litter types under seasonal temperature change.

Methods Senescing grass, buttercup, ash and oak litters were applied to soil lysimeters. Leachates were collected over 22 months and analysed for DOC and phenols. Phenols in litter and DOC were analysed using on-line
\end{abstract}

Responsible Editor: Ingrid Köegel-Knabner.

Electronic supplementary material The online version of this article (doi:10.1007/s11104-015-2678-z) contains supplementary material, which is available to authorized users.

J. S. Williams • G. D. Abbott

School of Civil Engineering and Geosciences, Drummond

Building, Newcastle University, Newcastle-upon-Tyne NE1 7RU, UK

G. D. Abbott

e-mail: geoff.abbott@ncl.ac.uk

J. S. Williams · J. A. J. Dungait $(\bowtie)$

Department of Sustainable Soils and Grassland Systems, Rothamsted Research, North Wyke, Okehampton, Devon EX20 2SB, UK

e-mail: jennifer.dungait@rothamsted.ac.uk

R. Bol

Institute of Bio- and Geosciences, IBG-3: Agrosphere, Forschungszentrum Jülich GmbH, 52425 Jülich, Germany e-mail: r.bol@fz-juelich.de thermally assisted hydrolysis and methylation with tetramethylammonium hydroxide (TMAH).

Results Mass loss differed between litter type (buttercup $>$ ash $>$ grass $>$ oak). Phenol concentrations in the senescing litters $(<2 \%$ TOC) were small, resulting in minor losses to water. Seasonal soil temperature positively correlated with DOC loss from litter-free soils. An initial correlation between temperature change and total phenol concentration in grass and ash litter treatment leachates diminished with time. Dissolved phenol variety in all litter-amended soil leachates increased with time.

Conclusions Plant-derived phenols from senescing litter made a minor contribution to DOC loss from soils. The strength of the relationship between seasonal temperature change and phenol type and abundance in DOC changed with time and was influenced by litter type.

Keywords Dissolved organic carbon - Leaf litter. Phenols · Seasonal temperature · Grassland soil

\section{Introduction}

Losses of dissolved organic carbon (DOC) from soils are amongst the least understood fluxes of the terrestrial carbon cycle. There is an economic and environmental imperative to understand and manage DOC inputs to improve water quality (Collins et al. 2013), and by the wider ambition to prevent soil organic carbon (SOC) losses to improve soil quality and to mitigate greenhouse gas emissions (Lal 2004). The transfer of organic 
carbon from plants to soil to waterways is governed by direct surface flows of particulate organic matter (POM) and sediment-associated organic carbon (Peukert et al. 2014), and sub-surface flows of DOC via hydrological pathways through the soil profile (Lloyd et al. 2012). The latter pathway is the most difficult to quantify because of the difficulty in meaningfully intercepting flows for measurement, and the general lack of knowledge about the factors that control the rates of turnover and loss of SOC as DOC (see recent review by Kaiser and Kalbitz 2012).

Understanding the temperature dependence of the rates of SOC processes is fundamental to determining the effect of global warming on soil C storage (Bol et al. 2003). The magnitude of change in the rate of SOC decomposition as temperature increases by 10 Kelvin $(\mathrm{K})$ is described by the Q10 parameter (Davidson and Janssens 2006). However, experimental warming of soils has been observed to increase or decrease the rate of SOC losses measured as $\mathrm{CO}_{2}$ efflux (Karhu et al. 2014). Moreover, the relationship between temperature variation and losses of SOC by leaching are less well explored. A correlation between increasing decadal mean summer temperatures and increased UK riverine DOC concentrations was reported by Worrall et al. (2003), but Benner and Kaiser (2011) observed larger DOC and lignin phenol concentrations in river water in winter compared with late spring.

The temperature sensitivity of the rate of decomposition is assumed to increase as substrate quality decreases (where quality is defined as 'the number of enzymatic steps required to release as $\mathrm{CO}_{2}$ a carbon atom from an organic compound'; Bosatta and Agren 1999). This phenomenon has been reported for forest soils (Bol et al. 2003; Waldrop and Firestone 2004; Kalbitz et al. 2007), grassland soils (Conant et al. 2008) and cultivated soils (Hartley and Ineson 2008), although Liski et al. (1999) suggested that the decomposition of old SOC in a boreal forest soil was resistant to temperature change. The chemical identity of the old 'stable' SOC pool has been sought in order to increase carbon sequestration by managing inputs of inherently recalcitrant organic matter, e.g. Lorenz et al. (2007). However, the idea that the resistance of SOC to decomposition can be based solely on its chemical structure has been disputed in favour of the wider role of environmental conditions such as soil moisture and temperature, and accessibility to decomposer organisms and/or their enzymes (Schmidt et al. 2011; Dungait et al. 2012) including stabilisation by organomineral interactions (Bol et al. 2009).

The variability in the rates of decomposition of different leaf litters correlates strongly with the physical and chemical characteristics of green leaves that persist through senescence (Cornwell et al. 2008). Phenols released from plant litter during decomposition derive from a range of protective biopolymers amongst which lignin is predominant, and tannins may also contribute substantially to tree leaf litter (Nierop and Filley 2007). Plant litter with relatively high lignin content is often described as having poor substrate quality (Grandy and Neff 2008). However, substantial lignin decomposition occurs in the initial stages of leaf decomposition (Klotzbücher et al. 2011a,b) and unmodified lignin is rarely detected in surface soil horizons (except in recognisable POM) where $48-87 \%$ of the initial lignin content in buried litter bags is degraded within 5 years (Thevenot et al. 2010). Indeed, contrasting responses of lignin decomposition in soils to temperature increases have been reported, ranging from an increase (Pisani et al. 2015), to no change (Zhang et al. 2011), to a decrease (Amelung et al. 1999). Austin et al. (2014) concluded that the lignin concentration of plant litters is not sufficient to explain the mechanistic patterns of litter decomposition in terrestrial ecosystems. Furthermore, lignin degradation has been shown to be monomer specific (Bahri et al. 2006; Dungait et al. 2008) and the transport of DOC through the soil may fractionate lignin degradation products through the processes of adsorption and desorption (Hernes et al. 2007) which are affected by temperature (Conant et al. 2011). Less is known about the fate of tannins which are a diverse group of secondary compounds that can hinder rates of decomposition by complexing with proteins (Kraus et al. 2003). As a consequence, uncertainty remains regarding the importance of the contribution of plant-derived phenols in general to DOC losses from litter to soils to waterways, and how abiotic factors including temperature change affect its rate of loss.

In this study, we tested the overall hypothesis that the release of phenols from plant litters from soils as a component of DOC is controlled by seasonal changes in temperature. This was investigated by allowing plant litter from contrasting vegetation types typical of local land uses in SW England to decompose naturally on soil lysimeters under controlled irrigation and exposed to near-to-natural temperature variation for 22 months. Phenol degradation in the litters and losses in 
leachates was analysed on-line using thermally assisted hydrolysis and methylation (THM) in the presence of tetramethylammonium hydroxide (TMAH).

\section{Materials and methods}

Experimental design

A well-drained, coarse, loamy soil (Rivington series; Eutric Endoleptic Cambisol; Landis 2015); 0-23 cm depth, from permanent pasture at Bicton College (East Budleigh, Devon, UK, SY070865) was sieved $(6.35 \mathrm{~mm})$ to homogenise soil chemistry ( $\mathrm{pH} 7.3)$ and remove large stones and plant residues. Twenty lysimeters were packed with $6.4 \mathrm{~L}$ sieved soil at optimum soilwater content $(17.2 \%)$ and bulk density $\left(\rho b=1.73 \mathrm{~g} \mathrm{~cm}^{-3}\right)$ and suspended on frames $300 \mathrm{~mm}$ above the ground to allow leachate collection and avoid a temperature gradient. Aluminium rings $(255 \mathrm{~mm}$ diameter, $127 \mathrm{~mm}$ height) were pressed into the lysimeter soil surfaces to a depth of approximately $10 \mathrm{~mm}$ to prevent boundary flow between the soil core and inner lysimeter wall. Three temperature data loggers (Tinytag) connected to sensors (PB-5002-IM5 10K NTC, www. tinytag.info) were inserted into the soil of three different lysimeters at $3 \mathrm{~cm}$ depth and programmed to record soil temperature every $30 \mathrm{~min}$.

'Brown' (senescing) plant litter was collected from different land use types at Rothamsted Research at North Wyke in Devon, UK (SX650995) in December 2009 to ensure that the litters were colonised by the natural litter decomposers for each location and stored at $4{ }^{\circ} \mathrm{C}$ until use. Grass litter was collected from agricultural grassland and divided into its dominant monocot grass (Lolium perenne and Holcus lanatus) and dicot buttercup (Ranunculus repens) species. Ash (Fraxinus excelsior) leaf litter was sampled from the floor of pure stands in managed agroforestry plots, and oak (Quercus robur) leaves were collected from the floor of unmanaged native woodland. Plant litter was applied to the soil surface of each of the 20 lysimeters to supply the same TOC (\%) per $\mathrm{m}^{2}$ (Table 2) in May 2010. The five treatments (four vegetation types plus no vegetation (control)) were applied at random to lysimeters by using a random number generator. The lysimeters were irrigated for $15 \mathrm{~s}$ with tap water (pH 7.7) every 7 days using nozzles mounted $10 \mathrm{~cm}$ above each lysimeter to maintain soil moisture. The nozzle mean flow rate for each lysimeter was $275 \mathrm{~mL} / \mathrm{min}$ to provide an even coverage of water to the vegetation litter surface.

Leachate sampling

Leachate samples were collected after 82 (August), 143 (October), 200 (December), 263 (February), 381 (June), 459 (August) and 671 (March) days. On each occasion, $2300 \mathrm{~mL}$ tap water was applied to the top of each lysimeter and the water allowed to drain for $2 \mathrm{~h}$ into weighed amber glass bottles (Fisher Scientific, part no. FB73180). The volume of water was calculated using the lysimeter soil pore volume $\left(2246 \mathrm{~cm}^{3}\right)$ to create piston-flow. The $\mathrm{pH}$ of the leachate was determined for a $10 \mathrm{~mL}$ sub-sample (Supplementary Table 1). The leachates were acidified to $\mathrm{pH} 2$ (trace analysis grade $\mathrm{HCl}$ acid, $37 \%$, Fisher Scientific). A subsample $(10 \mathrm{~mL})$ was analysed immediately for total organic carbon (TOC) concentration $\left(\mathrm{mg} \mathrm{L}^{-1}\right)$ using a TOC analyser (CA14 Formacs, Skalar (UK) Ltd). The carrier gas was purified air, supplied by a TOC gas generator (scrubbed of $\mathrm{CO}_{2}$ and moisture), and the inorganic catalyst solution was $2 \%$ orthophosphoric acid.

The remainder of the leachate was extracted using solid phase extraction (SPE) using a modified version of the method described by Louchouarn et al. (2000). Reverse phase $\mathrm{C}_{18}$ end capped solid phase extraction (SPE) cartridges $(60 \mathrm{~mL}, 10 \mathrm{~g}$, Mega-Bond Elut, Agilent Technologies) were mounted on a vacuum manifold (VAC ELUT-20, $13 \times 75 \mathrm{~mm}$, Varian) connected to a vacuum pump (Gast Diaphragm pump, model: DOAP504-BN. Gast Manufacturing, Inc. U.S.A.) via a liquid trap (Carboy Bottle 20 L, part 2226-0050 with filling venting closure, part 2161-0830, Varian Ltd.). Each cartridge was preconditioned with $100 \mathrm{~mL}$ methanol (HPLC grade, Fisher Scientific) followed by $50 \mathrm{~mL}$ pure water (MilliQ Gradient A10) acidified to $\mathrm{pH} 2$ (Trace analysis grade $\mathrm{HCl}$ acid, $37 \%$, Fisher Scientific). Leachate samples (approx. 2 L) were drawn through the SPE cartridges at an average flow rate of approximately $20 \mathrm{~mL} \mathrm{~min}^{-1}$ via a Teflon transfer pipe (1/8 in. $\times 0.1$ in. Part AL20096, Varian Ltd.) and adapters (part no. 12131004, Varian Ltd.). The cartridges were rinsed with $50 \mathrm{~mL}$ pure water $(\mathrm{pH} \mathrm{2})$ to remove any residual salts. Collection bottles $(60 \mathrm{~mL}$, Part BTF-543-030X, Fisher Scientific) were placed inside the vacuum manifold under each SPE cartridge prior to eluting the organic phase containing phenols with $50 \mathrm{~mL}$ methanol. The methanol was evaporated 
from the collection bottles at $40^{\circ} \mathrm{C}$ under a stream of $\mathrm{N}_{2}$ leaving the DOC residue for analysis.

\section{Sample analysis}

Dried and ground litter, soil and DOC residues were characterised for total organic C (TOC) and total N (TN) contents using a NA2000 analyser (Carlo Erba Instruments, Wigan, UK) and a 20-22 isotope ratio mass spectrometer (SerCon Ltd., Crewe, UK).

Individual phenols in litter, soil and DOC were directly analysed using thermally assisted hydrolysis and methylation (THM) with tetramethylammonium hydroxide (TMAH) using on-line pyrolysis gas chromatography mass spectrometry (Py-GC-MS). Samples were weighed $(0.5$ to $1.5 \mathrm{mg})$ into quartz pyrolysis tubes plugged with solvent-extracted glass wool. $5 \alpha-$ androstane in dichloromethane $(3 \mu \mathrm{L} ; 0.1 \mathrm{mg} / \mathrm{mL})$ was added as an internal standard to each pyrolysis tube. Immediately prior to analysis, $5 \mu \mathrm{L}$ of an aqueous solution of TMAH $(25 \%, w / w)$ was added to the sample. The tube was inserted into the platinum pyrolysis coil of a pyroprobe (CDS Pyroprobe 1000, CDS Analytical Inc.) and flash pyrolysed at $610{ }^{\circ} \mathrm{C}$ for $10 \mathrm{~s}$ $\left(20{ }^{\circ} \mathrm{C} \mathrm{ms}^{-1}\right.$ temperature ramp (Abbott et al. 2013). The pyroprobe interface (CDS 1500 valved interface, CDS Analytical Inc.) was maintained at $340{ }^{\circ} \mathrm{C}$ with the pyrolysis products passing into an HP6890 gas chromatograph (GC) with an open split $(30 \mathrm{~mL} / \mathrm{min})$ and a $60 \mathrm{~m}$ HP5-MS column $(0.25 \mathrm{~mm}$ internal diameter, $0.25 \mu \mathrm{m}$ film thickness, J\&W Scientific, USA). Helium was used as the carrier gas at a flow rate of $1 \mathrm{~mL} / \mathrm{min}$. The GC oven was programmed from 50 to $220{ }^{\circ} \mathrm{C}$ at a rate of $1.5^{\circ} \mathrm{C} / \mathrm{min}$, and then held isothermally for $1 \mathrm{~min}$, and then raised to a final temperature of $320^{\circ} \mathrm{C}$ at a rate of $15^{\circ} \mathrm{C} / \mathrm{min}$ and held isothermally for 16 min. Product detection was carried out using an HP5973 series mass selective detector in full scan mode ( $\mathrm{m} / \mathrm{z} 50$ to 700 ). Compound identification was based on the NIST98 mass spectral library, literature (Vane et al. 2001a, b; Vane 2003) and spectra from synthetic phenol standards (Table 1). Phenols were quantified using the internal standard approach, then normalised to $100 \mathrm{mg}$ OC using the sample TOC determined as described above. Total phenol concentrations were determined as the sum of the organic carbon normalised concentrations of the individual phenols detected.
Statistical analysis

GenStat (Release 14.1, VSN International Ltd., Hemel Hempstead, UK) was used to analyse all data using correlation, PCA and Analysis of variance (ANOVA) and specific differences were determined using the Fisher's protected least significant difference (FPLSD) test. A two-sample t-test was used to compare differences between the following parameters in litter vegetation: litter $\%$ mass loss, $\%$ TOC mass loss, $\%$ TN mass loss, and $\%$ phenol mass loss, within the same leaf litter type. Replication was 4 for vegetation and soil analysis and 3 for leachate analysis. Statistical significance was tested at the $95 \%$ level.

\section{Results}

Litter

Dry matter was greater in the leaves of the woody species oak and ash compared with the non-woody grasses and buttercup (Table 2). Mass loss after 671 days was in the order buttercup $>$ ash $>$ grass $>$ oak. Total organic carbon ranged from $49.1 \%$ in oak litter to $40.5 \%$ in buttercup litter initially, which was reduced to $43.9 \%$ (oak) and $33.3 \%$ (buttercup) at 671 days. The greatest TOC losses were observed in grass (6.8 \% loss) and the smallest in ash (5.4\% loss). Total nitrogen was significantly greater in buttercup $(4.1 \%)$ than in the other litters which ranged from $1.4 \%$ (ash) to $1.9 \%$ (grass), and TN losses after 671 days were very small or not detectable in any litter type. The largest changes in $\mathrm{C}: \mathrm{N}$ ratios were found in the woody species because of the larger relative TOC losses.

There was a trend for increased (up to double) total phenol concentrations in all degraded litter types (Table 3), where the greatest proportional increase was observed in buttercup (651 to $1384 \mu \mathrm{g} / 100 \mathrm{mg}$ OC). Initial phenol: $\mathrm{N}$ ratios were greatest in woody litter types ( 0.43 and 0.41 , for ash and oak, respectively), and least in buttercup (0.07; Table 2). The loss of total phenols was $74 \%$ (buttercup), $40 \%$ (ash), $29 \%$ (oak), and $24 \%$ (grass) of the initial concentration, but there were no significant differences between litter types because of the large variation in concentration between individual phenols. After 671 days, phenol: $\mathrm{N}$ ratios had increased in the herbaceous species, but decreased in the woody species. Some relative differences in individual 
Table 1 Phenols (with abbreviations) identified in litter, soils and leachates using thermally assisted hydrolysis and methylation on inline pyrolysis gas chromatography mass spectrometry (Py-GC-MS)

\begin{tabular}{lll}
\hline Abbreviation & Compound & Mass ions (m/z) \\
\hline P1 & Methoxybenzene & $65,77,108$ \\
P2 & 4-methoxytoluene & $91,107,122$ \\
G1 & 1,2-dimethoxybenzene & $95,123,138$ \\
P3 & 4-methoxybenzeneethylene & $91,119,134$ \\
G2 & 3,4-dimethoxytoluene & $109,137,152$ \\
S1 & 1,2,3-trimethoxybenzene & $110,153,168$ \\
P24 & 4-methoxybenzeneacetic acid & $91,121,180$ \\
G3 & 3,4-dimethoxybenzeneethylene & $121,149,164$ \\
P6 & 4-methoxybenzoic acid methyl ester & $77,135,166$ \\
S2 & 3,4,5-trimethoxytoluene & $139,167,182$ \\
G4 & 3,4-dimethoxybenzaldehyde & $151,165,166$ \\
G21 & 1-(3,4-dimethoxyphenyl)-3-propene & $147,163,178$ \\
G5 & 3,4-dimethoxyacetophenone & $137,165,180$ \\
G6 & 3,4-dimethoxybenzoic acid methyl ester & $165,181,196$ \\
S4 & 3,4,5-trimethoxybenzaldehyde & $125,181,196$ \\
G24 & 3,4-dimethoxybenzeneacetic acid methyl ester & $107,151,210$ \\
S21 & 1-(3,4,5-trimethoxyphenyl)-3-propene & $193,161,192$ \\
P18 & 2-Propenoic acid, 3-(4-methoxyphenyl) methyl ester (E)- & $139,195,210$ \\
S5 & 3,4,5-trimethoxyacetophenone & $195,211,226$ \\
S6 & 3,4,5-trimethoxybenzoic acid methyl ester & $191,207,222$ \\
G18 & 2-propenoic acid, 3-(3,4-dimethoxyphenyl) methyl ester & \\
\hline & & \\
\hline
\end{tabular}

phenol concentrations between litter types were observed, but these were different in the initial litter (0 days) compared to the degraded litter (671 days; Fig. 1). There was a trend for the relative abundances of phenols to increase that was more pronounced in the non-woody litter types (Table 2). For example, the initial oak litter was different from the other litter types based on the greater relative abundance of S6 $(184.5 \pm 61.8 \mu \mathrm{g}$ $100 \mathrm{mg}$ OC) and G2 (162.6 $\pm 13.8 \mu \mathrm{g} 100 \mathrm{mg} \mathrm{OC})$ phenols in particular (Fig. 1; Table 3). After 671 days, there was no distinction between grass, ash and oak litter, but the buttercup litter separated in the PCA plot

Table 2 Soil and litter (grass, buttercup, ash, and oak) characteristics at the beginning ( 0 days) and end (671 days) of the lysimeter experiment. Values are mean $(n=4) \pm 1$ s.e.

\begin{tabular}{|c|c|c|c|c|c|c|}
\hline Days & & $\begin{array}{l}\text { Soil (control) } \\
\% \text { dry weight }\end{array}$ & Grass & Buttercup & Ash & Oak \\
\hline \multirow[t]{5}{*}{0} & Dry matter & - & $16.3(1.1)$ & $12.6(0.5)$ & $22.1(1.3)$ & $25.5(1.0)$ \\
\hline & TOC & $1.3(0.19)$ & $43.8(0.46)$ & $40.5(0.53)$ & $47.1(0.18)$ & $49.1(0.28)$ \\
\hline & $\mathrm{TN}$ & $0.1(0.00)$ & $1.9(0.10)$ & $4.1(0.22)$ & $1.4(0.04)$ & $1.6(0.05)$ \\
\hline & $\mathrm{C}: \mathrm{N}$ & 13 & 23 & 10 & 34 & 31 \\
\hline & Phenols:N & - & 0.31 & 0.07 & 0.43 & 0.41 \\
\hline \multirow[t]{5}{*}{671} & Mass loss & - & $38.9(0.6)$ & $83.4(4.6)$ & $42.9(2.5)$ & $22.7(0.7)$ \\
\hline & TOC & $0.6(0.14)$ & $37.0(0.85)$ & $33.8(2.41)$ & $41.7(0.90)$ & 43.9 (1.14) \\
\hline & $\mathrm{TN}$ & $0.1(0.01)$ & $1.9(0.06)$ & $3.9(0.33)$ & $1.7(0.06)$ & $1.7(0.05)$ \\
\hline & $\mathrm{C}: \mathrm{N}$ & 6 & 19 & 9 & 25 & 26 \\
\hline & Phenols:N & - & 0.38 & 0.12 & 0.35 & 0.37 \\
\hline
\end{tabular}


Table 3 Mean $( \pm 1$ s.e.; $n=4)$ normalised $(\mu \mathrm{g} / 100 \mathrm{mg}$ OC) phenol concentrations from TMAH/py-GC-MS analysis of grass, buttercup, ash and oak litters after 0 and 671 days. Total phenols (sum of all phenols) and acid/aldehyde ratios: G6/G4 and S6/S4 are also reported

\begin{tabular}{|c|c|c|c|c|c|c|c|c|}
\hline \multirow{2}{*}{$\begin{array}{l}\text { Days } \\
\text { Compound }\end{array}$} & \multicolumn{4}{|l|}{0} & \multicolumn{4}{|l|}{671} \\
\hline & $\begin{array}{l}\text { Grass } \\
\mu \mathrm{g} / 100 \mathrm{mg} \mathrm{OC}\end{array}$ & $\begin{array}{l}\text { Buttercup } \\
\text { C }\end{array}$ & Ash & Oak & Grass & Buttercup & Ash & Oak \\
\hline $\mathrm{P} 1$ & $75.5(14.8)$ & $80.8(19.7)$ & $81.8(8.0)$ & $57.5(5.9)$ & $158.2(29.5)$ & $298.5(134.5)$ & $168.1(32.0)$ & $141.1(21.2)$ \\
\hline $\mathrm{P} 2$ & $72.1(9.3)$ & $93.8(26.8)$ & $67.8(11.0)$ & $104.3(5.0)$ & $134.2(20.8)$ & $411.1(184.6)$ & $196.2(43.7)$ & $97.6(11.6)$ \\
\hline G1 & $27.8(4.3)$ & $59.9(18.7)$ & $58.3(11.3)$ & $22.1(11.9)$ & $120.7(24.1)$ & $79.1(19.1)$ & $129.0(49.1)$ & $102.2(44.1)$ \\
\hline P3 & $69.2(6.7)$ & $18.4(3.7)$ & $44.8(16.0)$ & $40.3(10.4)$ & $127.9(31.6)$ & $28.6(8.2)$ & $66.3(10.7)$ & $76.3(26.2)$ \\
\hline $\mathrm{G} 2$ & $20.7(4.9)$ & $11.3(11.3)$ & $33.8(8.1)$ & $162.6(13.8)$ & $102.3(19.7)$ & $9.5(9.5)$ & $69.2(18.8)$ & $202.2(29.0)$ \\
\hline $\mathrm{S} 1$ & $35.8(6.1)$ & $48.2(14.5)$ & $50.2(15.1)$ & $64.5(2.8)$ & $41.7(20.3)$ & $21.1(10.4)$ & $45.8(16.8)$ & $82.0(38.1)$ \\
\hline $\mathrm{P} 24$ & n.d. & n.d. & $63.5(38.3)$ & n.d. & n.d. & n.d. & $25.2(12.7)$ & n.d. \\
\hline G3 & $280.5(54.0)$ & $122.3(40.6)$ & $215.7(60.4)$ & $166.2(17.6)$ & $293.3(31.1)$ & $62.0(20.7)$ & $139.9(40.4)$ & $173.4(28.3)$ \\
\hline P6 & $98.4(23.8)$ & $24.4(6.6)$ & $26.9(10.5)$ & n.d. & $96.7(30.6)$ & $66.1(37.2)$ & $15.0(2.7)$ & $14.4(3.0)$ \\
\hline $\mathrm{S} 2$ & $11.7(4.7)$ & $17.1(5.6)$ & $10.7(4.4)$ & $33.2(10.3)$ & $15.9(6.3)$ & $12.9(5.4)$ & $24.9(9.5)$ & $25.7(9.4)$ \\
\hline G4 & $31.0(3.1)$ & $6.1(3.6)$ & $33.8(11.6)$ & $39.2(9.3)$ & $42.7(13.4)$ & $5.9(3.4)$ & $38.1(20.5)$ & $28.1(11.4)$ \\
\hline G21 & $8.9(3.6)$ & n.d. & $18.5(3.8)$ & $29.5(5.2)$ & $20.5(3.5)$ & $7.2(5.3)$ & $33.0(10.9)$ & $37.7(18.1)$ \\
\hline G5 & $37.7(11.2)$ & n.d. & $63.4(18.3)$ & $74.4(37.5)$ & $39.1(1.1)$ & $73.5(37.8)$ & $31.7(11.5)$ & $82.6(6.8)$ \\
\hline G6 & $30.7(5.8)$ & $44.7(14.1)$ & $62.2(24.3)$ & $56.6(15.2)$ & $62.3(8.5)$ & $101.8(51.3)$ & $59.0(18.8)$ & $58.5(16.4)$ \\
\hline $\mathrm{S} 4$ & $13.8(1.9)$ & n.d. & $28.1(14.6)$ & $18.6(6.2)$ & n.d. & n.d. & $1.9(1.9)$ & $5.1(3.0)$ \\
\hline G24 & n.d. & n.d. & $15.2(8.3)$ & n.d. & $4.5(4.5)$ & n.d. & $2.0(1.3)$ & $12.6(2.9)$ \\
\hline S21 & $2.2(0.817)$ & n.d. & $51.4(21.6)$ & $49.0(5.1)$ & $9.9(5.7)$ & n.d. & $25.8(8.9)$ & $46.7(12.6)$ \\
\hline P18 & $176.0(16.1)$ & $8.4(3.4)$ & $43.7(16.0)$ & $101.0(34.8)$ & $183.7(42.6)$ & $28.4(9.6)$ & $50.4(14.5)$ & $51.5(7.3)$ \\
\hline S5 & $24.3(2.7)$ & $10.0(2.3)$ & $13.4(7.0)$ & $27.5(1.6)$ & $27.9(10.4)$ & $54.7(33.1)$ & $14.6(3.3)$ & $8.2(1.95)$ \\
\hline S6 & $36.4(7.7)$ & $9.8(2.7)$ & $20.2(12.3)$ & 184.5 (61.8) & $53.4(20.6)$ & $65.1(40.8)$ & $17.9(8.6)$ & $79.2(23.8)$ \\
\hline G18 & $290.6(43.7)$ & $66.2(12.4)$ & $273.6(127.8)$ & $14.3(2.1)$ & $233.7(62.1)$ & $51.2(26.1)$ & $205.0(96.3)$ & $11.1(2.0)$ \\
\hline Total phenols & 1366 (189) & $651(171)$ & 1303 (379) & 1297 (202) & $1909(151)$ & $1384(550)$ & $1421(368)$ & $1450(172)$ \\
\hline
\end{tabular}

n.d. not detected

based on the relative abundance of P2 $(411.1 \pm 184.6 \mu \mathrm{g}$ $100 \mathrm{mg} \mathrm{OC})$ and G6 $(101.8 \pm 51.3 \mu \mathrm{g} 100 \mathrm{mg}$ OC $)$ phenols, and relatively lower abundance of G2 $(9.5 \pm 9.5 \mu \mathrm{g} 100 \mathrm{mg}$ OC) and G3 $(62.0 \pm 20.7 \mu \mathrm{g}$ $100 \mathrm{mg}$ OC) compared with the other litter types (Fig. 1b; Table 3).

\section{Soil}

The control soil TOC was reduced from 1.3 to $0.6 \%$ after 671 days (Table 2). There was no detectable change in TN. The detectable total phenol concentration of the soil was $60 \pm 22 \mu \mathrm{g} / 100 \mathrm{mg}$ OC. The detectable phenols were P1 (19 $\pm 8 \mu \mathrm{g} / 100 \mathrm{mg} \mathrm{OC}), \mathrm{P} 2(10 \pm 7 \mu \mathrm{g} /$ $100 \mathrm{mg}$ OC), P6 (18 $\pm 18 \mu \mathrm{g} / 100 \mathrm{mg}$ OC $), \mathrm{G} 6(8 \pm 8 \mu \mathrm{g} /$ $100 \mathrm{mg} \mathrm{OC})$ and $\mathrm{S} 6(19 \pm 8 \mu \mathrm{g} / 100 \mathrm{mg}$ OC) .
Leachates

\section{Dissolved organic carbon}

There was a significant positive correlation $\left(\mathrm{r}^{2}=0.6917\right)$ between soil temperature change (annual mean $11^{\circ} \mathrm{C}$; summer maximum $34{ }^{\circ} \mathrm{C}$; winter minimum $-7{ }^{\circ} \mathrm{C}$; Fig. 2a) and corresponding maximum DOC concentrations in leachates from the control soil in the summer of year 1 (82 days; $6.55 \mathrm{mg} \mathrm{C/L}$ ) and year 2 (459 days; $7.47 \mathrm{mg} \mathrm{C} / \mathrm{L}$ ) and minima in winter (263 days; $2.47 \mathrm{mg}$ C/L; Fig. 2b). Correlations between soil temperature change and DOC concentrations were weaker in litter treated soils (Fig. 3; $\mathrm{r}^{2}=0.1331,0.1023,0.2470$, and 0.0335 for grass, buttercup, ash and oak treatments, respectively) because the different litters exhibited different trends. DOC in leachates from ash litter-treated 


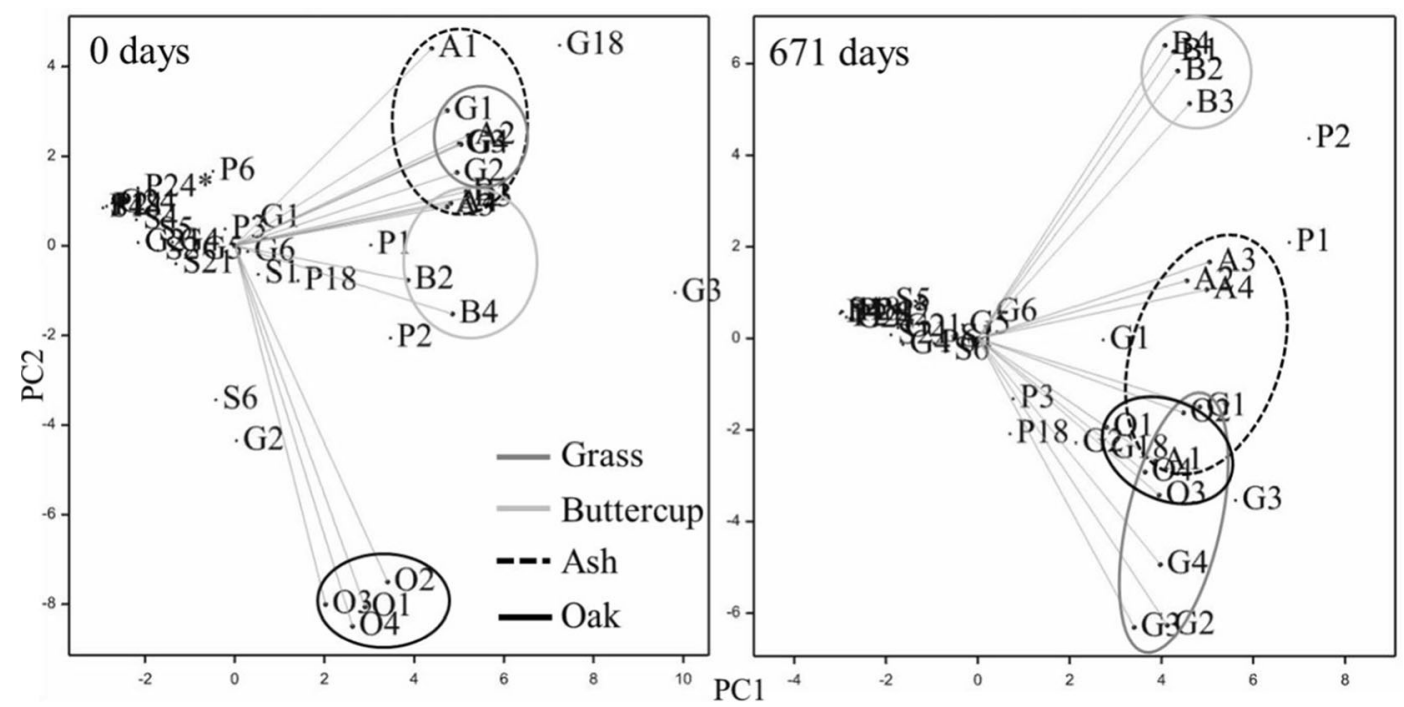

Fig. 1 Principal component analysis of first and second components of individual phenol concentrations (abbreviation definitions given in Table 1), and variates: grass (G), buttercup (B), ash (A), and oak (O) litter samples. Numbers 1 to 4 identify replicates

soil increased over time (Fig. 3c), whereas those for grass (Fig. 3a) and buttercup (Fig. 3b) leachates showed a trend to decrease through time, and fluctuated before reaching a stable concentration in oak leachates (Fig. 3d). Concentrations of DOC in leachates differed between plant litter treatments at different times of the year. Maximum OC measured in leachates differed between litter treatments in the order: grass litter $45.89 \pm 9.02 \mathrm{mg} \mathrm{C} / \mathrm{L}$ (143 days; Fig. 3a) > ash litter $21.04 \pm 1.26 \mathrm{mg} \mathrm{C} / \mathrm{L}$ in (523 days; Fig. 3c) $>$ oak litter $17.66 \pm 4.22 \mathrm{mg} \mathrm{C} / \mathrm{L}$ (312 days; Fig. 3d) > buttercup litter $12.16 \pm 2.57 \mathrm{mg} \mathrm{C/L}$ (200 days; Fig. 3b).

\section{Total phenols in leachates}

Unlike the DOC concentrations, the DOC normalised total phenol concentrations in leachates from the control treatment did not correlate with temperature $\left(\mathrm{r}^{2}=0.1362\right)$ but reduced progressively with time from $0.43 \pm 0.01 \mu \mathrm{g} / 100 \mathrm{mg}$ OC ( 82 days) to $0.18 \pm 0.00 \mu \mathrm{g} /$ $100 \mathrm{mg}$ (671 days; Fig. 2c). Total phenol concentrations in leachates from the litter-treated soils were always greater than the control treatment, and correlations with soil temperature change over the duration of the experiment were: $r^{2}=0.1549,0.1977,0.1218$, and 0.1877 for grass, buttercup, ash and oak litters, respectively (Fig. 3a, b, and c). However, there was a significant positive correlation between the release of total phenols in leachates from the grass treatment and seasonal temperature until June in the second year $\left(\mathrm{R}^{2}=0.9069\right.$,
$P<0.02)$ and a significant positive correlation between total phenols leached from the ash treatment and temperature until February in the second year $\left(\mathrm{R}^{2}=0.9838\right.$, $P<0.02)$. The correlation between phenol concentration and temperature was weaker in buttercup leachates $\left(\mathrm{R}^{2}=0.5628\right.$ until June in the second year), and no correlation was observed in the leachates of the oak litter treatment where the total phenolic content increased progressively with time from 0.66 to $0.98 \mu \mathrm{g} /$ $100 \mathrm{mg}$ OC (Fig. 3d). The maximum total phenol concentrations differed between litter treatments in the order: ash litter $(4.24 \pm 0.04 \mu \mathrm{g} / 100 \mathrm{mg}$ OC; 671 days $)>$ buttercup litter $(3.16 \pm 0.04 \mu \mathrm{g} / 100 \mathrm{mg}$ OC; 381 days $)>$ grass litter $(2.69 \pm 0.03 \mu \mathrm{g} / 100 \mathrm{mg} \mathrm{OC}$; 671 days $)>$ oak litter $(0.98 \pm 0.02 \mu \mathrm{g} / 100 \mathrm{mg}$ OC; 671 days).

\section{Individual phenols in leachates}

The concentrations of individual phenols (with concentrations greater than $0.05 \mu \mathrm{g} / 100 \mathrm{mg} \mathrm{OC}$ ) in the leachates from the control treatment remained relatively constant through time, except $\mathrm{P} 1$ which decreased $(0.20$ to $0.05 \mu \mathrm{g} / 100 \mathrm{mg}$ OC, Fig. 4, Supplementary Table 2). Individual phenols in leachates from the soils treated with grass, buttercup, and ash litter types were similar in identity, and the variety of phenols increased with time and was most diverse at peak total phenol concentrations, in June (381 days) and March (671 days) (Fig. 3a, b, c). For example, P1 was detected in all 
Fig. 2 The relationship between a soil temperature and mean $(n=3) \mathbf{b}$ dissolved organic carbon concentrations (mg C/L) and c total phenol concentrations in leachates collected from control (no litter) soil lysimeters after 82, $143,200,263,381,459$, and 671 days. Error bars indicate \pm 1 s.e

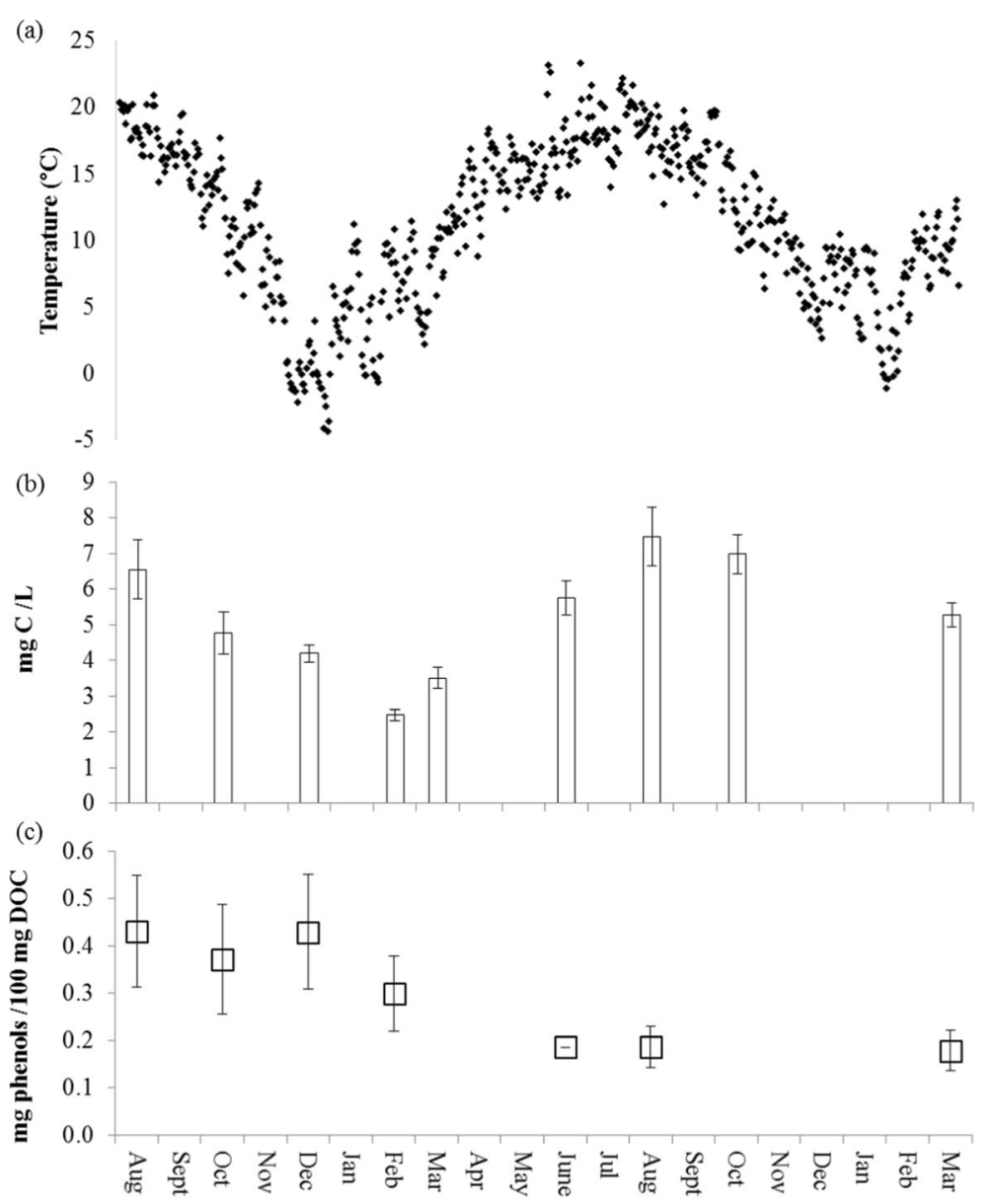

leachates in relatively high abundances throughout the incubation, i.e. after 82 days in grass $(0.69 \pm 0.53 \mu \mathrm{g} /$ $100 \mathrm{mg}$ OC), buttercup $(0.49 \pm 0.21 \mu \mathrm{g} / 100 \mathrm{mg}$ OC), ash $(0.53 \pm 0.41 \mu \mathrm{g} / 100 \mathrm{mg}$ OC) and oak $(0.27 \pm 0.09 \mu \mathrm{g} / 100 \mathrm{mg}$ OC) litter treatments, and after 671 days in grass $(0.54 \pm 0.10 \mu \mathrm{g} / 100 \mathrm{mg} \mathrm{OC})$ and ash $(0.62 \pm 0.21 \mu \mathrm{g} / 100 \mathrm{mg}$ OC) but not buttercup litter treatments where concentrations had declined to $0.16 \pm 0.05 \mu \mathrm{g} / 100 \mathrm{mg}$ OC at 671 days from a maximum of $0.53 \pm 0.37 \mu \mathrm{g} / 100 \mathrm{mg}$ OC at 381 days. Greater concentrations of G6 were associated with greater concentrations of S6 in leachates of all litter types in the latter half of the experiment. G6 was the most abundant phenol in leachates from ash litter treatments determined at $0.82 \pm 0.26 \mu \mathrm{g} / 100 \mathrm{mg} \mathrm{OC}$ and second most abundant phenol from grass litter treatments $(0.45 \pm 0.21 \mu \mathrm{g} /$ $100 \mathrm{mg}$ OC) after 671 days, respectively; $0.50 \pm 0.36 \mu \mathrm{g} / 100 \mathrm{mg}$ OC after 381 days for the buttercup litter treatment; and, $0.30 \pm 0.13 \mu \mathrm{g} / 100 \mathrm{mg}$ OC after 459 days in the oak litter treatment. P3 was only detected $>0.05 \mu \mathrm{g} / 100 \mathrm{mg}$ OC after 381 days in the leachates from the ash treatment. P24 and G24 were only identified in the leachates $(>0.05 \mu \mathrm{g} / 100 \mathrm{mg}$ OC) from the buttercup and ash treatments, respectively.

\section{Discussion}

Litter degradation varied between plant types

Using senescent leaves of four dominant local plant types as the treatment in this study, we observed the relationship between plant type and decomposition as: buttercup $>$ ash $>$ grass $>$ oak. This agrees with a recent meta-analysis of the published global data by Cornwell et al. (2008) relating to the relationships between leaf litter traits and decomposition rates, who observed that the litter from graminoid species did not necessarily decompose faster than woody species litter. The woody species used in this study were likely to have 

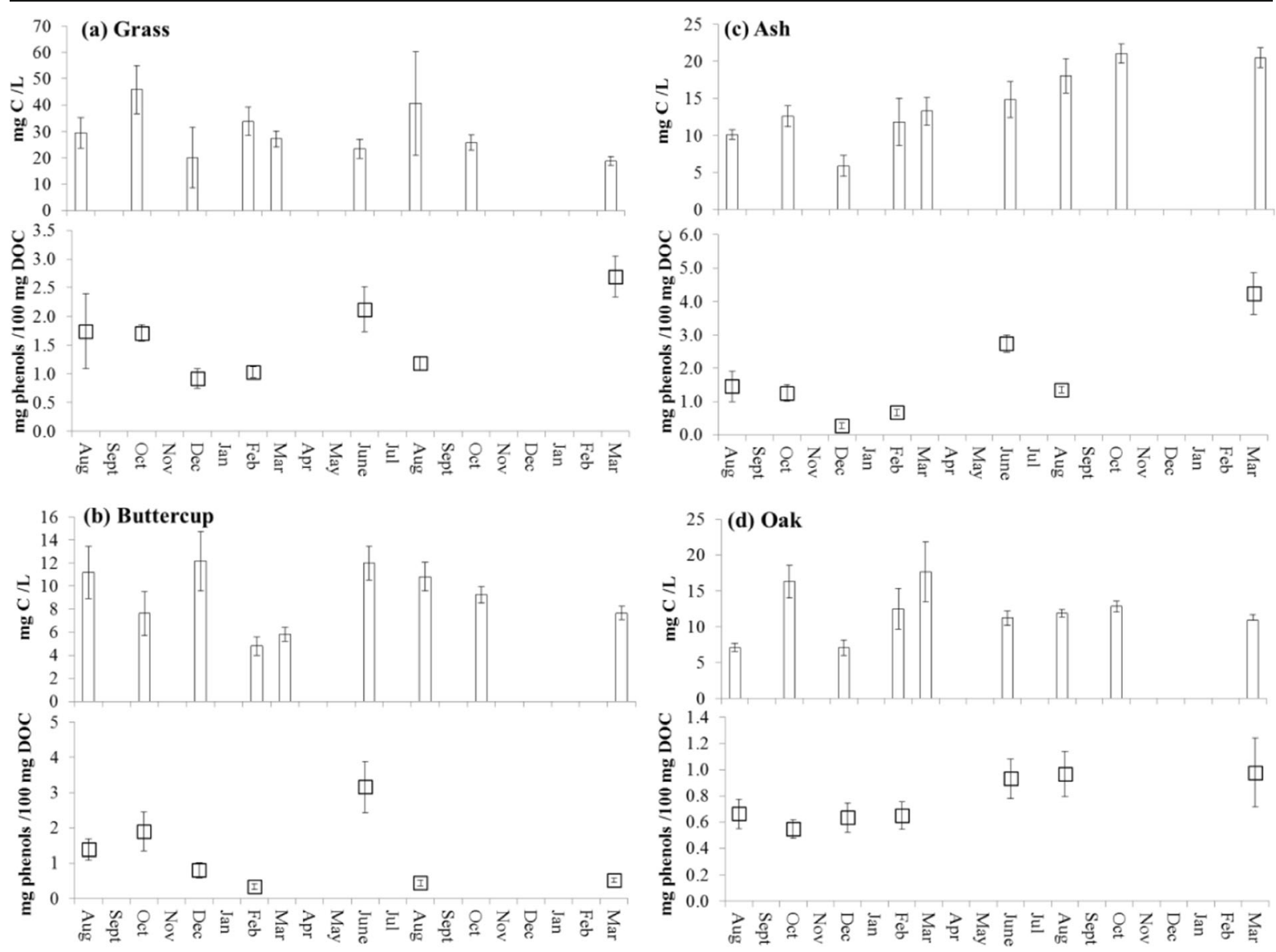

Fig. 3 Mean $(n=3)$ dissolved organic carbon concentrations (mg $\mathrm{C} / \mathrm{L})$ and total phenol concentrations $(\mu \mathrm{g} / 100 \mathrm{mg} \mathrm{C})$ in leachates collected from soil lysimeters treated with a grass, b buttercup, c

ash and $\mathbf{d}$ oak litters after 82, 143, 200, 263,381, 459, and 671 days. Error bars indicate \pm 1 s.e

different decomposition rates; Riutta et al. (2012) described ash as 'easily decomposable' and oak as 'decomposition resistant' and observed that leaves from freshly fallen ash and oak leaves lost $87 \%$ and $57 \%$ mass, respectively, in a 3 month litter incubation in UK woodland. Buttercup litter decomposed fastest ( $83 \%$ in 671 days), and had the lowest $\mathrm{C}: \mathrm{N}$ ratio because it contained two- to three-times more $\mathrm{N}$ than the other litter types, suggesting a relationship between litter $\mathrm{N}$ and decomposition rate. The reduced availability of $\mathrm{N}$ may inhibit decomposition where $\mathrm{N}$ supply is limited, e.g. in high C:N litters (e.g. wheat straw; Mary et al. 1996) or increase it because the activity of fungi which can degrade lignin to $\mathrm{CO}_{2}$ are repressed by high $\mathrm{N}$ substrates (Berg and McClaugherty 2014). However, the proportion of $\mathrm{N}$ in all litter types did not change during the experiment, even in the buttercup, suggesting that easily available $\mathrm{N}$ was lost before the litter was collected, similar to that reported by Sanaullah et al. (2010) for 'brown' litters. This indicates that the $\mathrm{N}$ remaining in the senesced litters was in a form that was resistant to decomposition, i.e. through the formation of polyphenol-protein condensates via the reaction of carbonyl $(\mathrm{C}=\mathrm{O})$ groups in [partially oxidised] lignin with $\mathrm{NH}_{2}$ groups to form Schiff bases, or complexes of tannins with proteins via ionic and hydrogen bonding or hydrophobic interactions that are assumed to resist microbial degradation (see the review by Knicker 2011). The oak litter had the slowest rate of decomposition (23\% mass loss) of the four plant types which may be ascribed to the larger relative abundance of tannins in this litter type (Filley et al. 2006). However, the source of the litter $\mathrm{N}$ that was measured was not defined, so it cannot be ruled out that a proportion may have been 
(a) Control

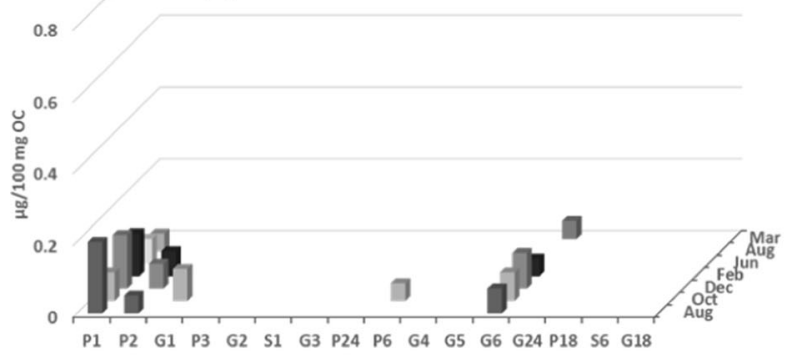

(c) Buttercup

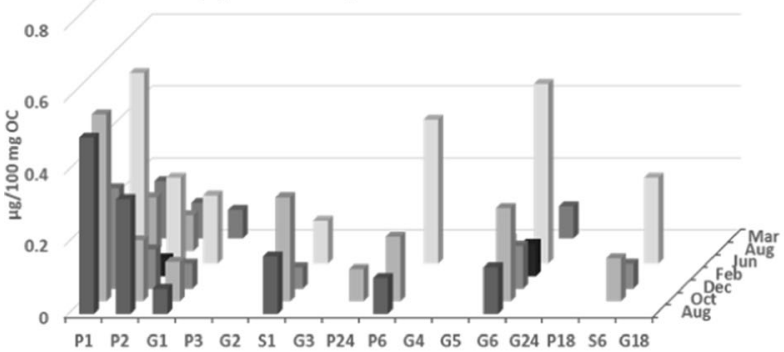

(e) Oak

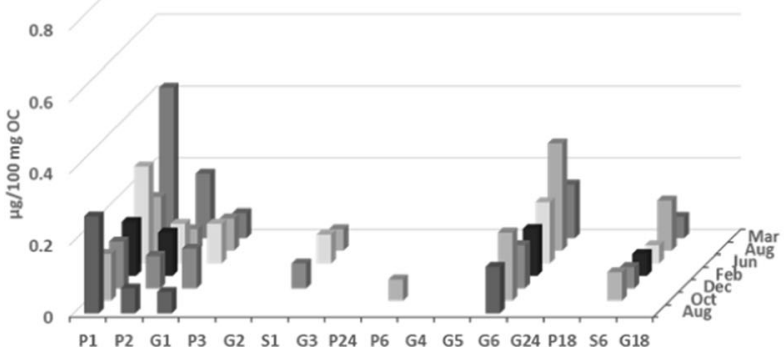

(b) Grass
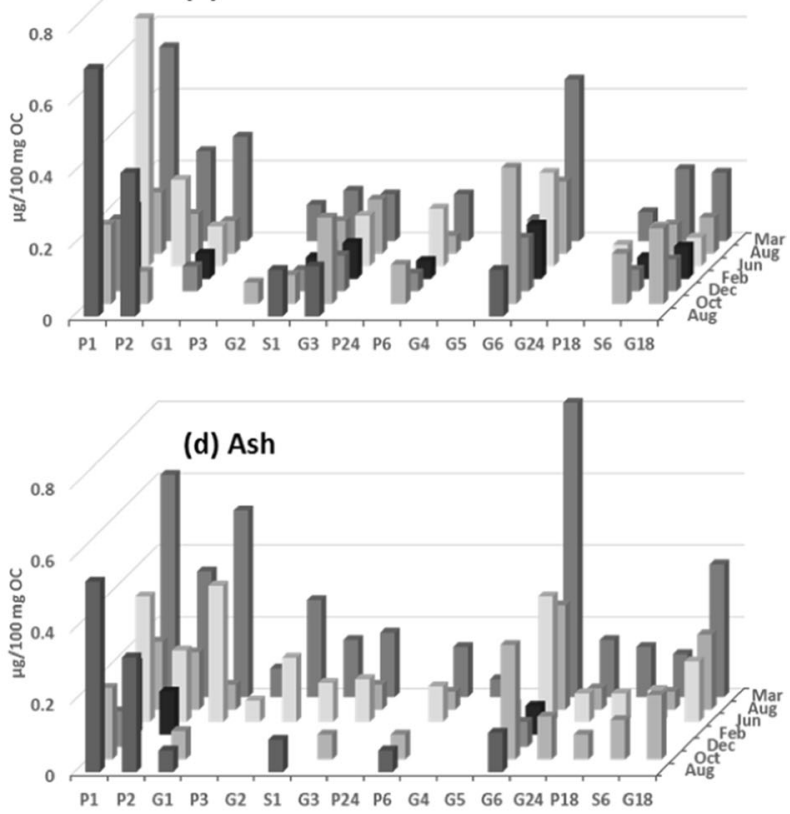

Fig. 4 Mean concentrations of phenols in leachates from soils treated with a no litter (control), $\mathbf{b}$ grass litter, $\mathbf{c}$ buttercup litter, $\mathbf{d}$ ash litter and es oak litter after 82, 143, 200, 263, 381, 459, and 671 days. (Mean values and standard errors given in Supplementary Table 2)

derived from the colonising decomposers; Zeller et al. (2000) reported that up to $35 \%$ of litter $\mathrm{N}$ was microbial after 3 years.

Lignin is widely reported to account for a large percentage of the dry weight of leaves and leaf litter, e.g. 10 to $24 \%$ of fresh leaves from a range of broadleaved deciduous trees (Melillo et al. 1982); 28 to $51 \%$ of fresh leaf litter of coniferous and broad-leaved deciduous trees (Berg et al. 2007); and, 3, 4 and $10 \%$ of senescent cereal straw, pasture grass and native woodland litter, respectively (Walela et al. 2014). However, the gravimetric analytical methods used in many studies (including those listed above) to 'quantify' lignin may lead to a substantial overestimation because the 'lignin fraction' includes a range of non-lignin substances that are resistant to strong acids or detergents. A recent study by Klotzbücher et al. (2011a) compared three widelyused methods for lignin analysis and determined very large differences between the lignin content estimated for a range of tree leaves, e.g. $\sim 2, \sim 5$ and $\sim 50 \%$ litter $\mathrm{C}$, respectively, from ${ }^{13} \mathrm{C}$-TMAH thermochemolysis, $\mathrm{CuO}$ oxidation and acid detergent lignin (ADL) analyses of ash leaves that had been incubated for 3 months. Although an underestimation of lignin using the former two methods is suspected (because of the preferential cleavage of specific bonds by either method), there is a difference of an order of magnitude compared with the results of ADL. The application of TMAH in this 
experiment to the initial senesced litters detected total phenols ranging from $<1.0 \%$ (buttercup) to $1.4 \%$ (grass) litter $\mathrm{C}$, and between $1.4 \%$ (buttercup) and $2.0 \%$ (grass) litter $\mathrm{C}$ after 671 days (Table 3). This relatively minor contribution to leaf dry matter in senesced leaves concurs with the emerging idea put forward by Klotzbücher et al. (2011b), that lignin degradation in the early stages of litter decomposition is pronounced with the majority lost as $\mathrm{CO}_{2}$, and that lignin input to soil (and therefore lost in leachates) is actually rather minor.

Chabbi and Rumpel (2004) and Sanaullah et al. (2012) reported that during the first phase $(<11$ months) of decomposition plant material is degraded as a whole, rather than selectively, and during the second phase (>11 months) more readily degradable components such as polysaccharides are selectively degraded. The stage of decomposition of the senescing litters used in this experiment was unknown. However, as previously reported for decomposing grasses (Sanaullah et al. 2010; Bray et al. 2012) and tree leaves (Klotzbücher et al. 2011a) we observed an increase in the proportion of total phenols remaining in all litter types after 671 days. Furthermore, the contributing phenols had changed in relative abundance (Fig. 1), suggesting that different monomers were released from the leaf litter at different rates in different plant types. Moreover, we investigated phenol decomposition from single species in isolation over a time course extending beyond 1 year. It is acknowledged that in vivo each individual species and coexisting vegetation would contribute more litter, and also that natural populations of litter and soil meso- and macrofauna can considerably alter litter decomposition rates, despite unaltered climatic conditions and litter chemistry (Hattenschwiler and Gasser 2005). Furthermore, the ramification of the litter by fungal mycelia which decompose lignin specifically (Robertson et al. 2008) and increase DOC production (Kalbitz et al. 2000) were likely excluded from this study by experimental sampling preparation and design. The use of grassland soils for the experiment may have also conferred 'home field advantage' on the grass and buttercup treatments wherein the soil microbial community was already adapted to this litter type (Austin et al. 2014), and was potentially more compatible with the microbial community in the senescing grass and buttercup litter than with that in the ash and oak litter.
Effect of seasonal temperature change on DOC loss from soils

Future temperature increases will change SOC decomposition patterns by affecting soil microbial community dynamics and substrate utilization (Pisani et al. 2015), and temperature-dependant processes affecting the release of DOC from soils, e.g. sorption or immobilisation that are controlled by microbial activity (Marschner and Bredow 2002) or physicochemical factors, e.g. dissolution, diffusion and exchange reactions (Toosi et al. 2014). Peak DOC concentrations in soils are generally observed during the summer due to increased inputs from root exudates and the elevated activity of decomposers in plant litter and soil, and (in temperate and tropical regions) enhanced by the effect of wet-dry cycles which have physical impacts on soil function and biological activity (Placella et al. 2012). In the control soils, in the absence of plant litter, a significant positive relationship between mean soil temperature and the concentrations of DOC leached from the lysimeters was detected which we assume was the direct impact of temperature on the soil microbial biomass, often observed as changes in respiration in similar experiments using unplanted, packed soils e.g. Karhu et al. (2014). More than half the initial TOC concentration was lost in the control soil by the end of the experiment $(0.6 \%)$, but we did not observe a coincident reduction in the loss of DOC over time. This suggests that the processes controlling the release of DOC were not limited by the biological availability of SOC within the timescale of the experiment, i.e. that the SOC was sufficiently abundant and bioavailable to permit the observation of seasonal DOC trends. Alternative mechanisms for the supply of SOC that rely on its abiotic release from stabilised SOC have been hypothesised but are difficult to test experimentally due to the challenge to separate biotic from abiotic mechanisms in soils (Kemmitt et al. 2008; Paterson 2009; Toosi et al. 2012).

The DOC leached from soil was very small; therefore, we assume that the vast majority of applied litterderived $\mathrm{OC}$ either remained in the soil or was oxidised to $\mathrm{CO}_{2}$ (as observed by Klotzbücher et al. 2011b). Nevertheless, the DOC losses were much larger from the litter-treated soils, but no correlation was observed between temperature and DOC loss. Different patterns of DOC loss were determined between different litter types, e.g. an increased leaching of DOC over time in the ash treatment from December in year 1 compared to 
a stable rate of loss from the oak treatment after June in year 2. The explanation for the differences is very difficult to define and must incorporate a range of physicochemical and biological mechanisms in the litter and soils. The purely physical transport of largely unmodified litter-derived water transportable organic matter through the soil matrix as soluble compounds in leachates or colloids, modified by adsorption/desorption (Kaiser and Kalbitz 2012), could explain the increase in DOC from the treated lysimeters. The source of the carbon (litter or SOC) in DOC has been investigated using stable $\left({ }^{13} \mathrm{C}\right)$ or radio $\left({ }^{14} \mathrm{C}\right)$-isotopes to differentiate source (Kahl et al. 2012; Tipping et al. 2012; Toosi et al. 2012; Scheibe and Gleixner 2014), so compoundspecific stable isotope analyses of ${ }^{13} \mathrm{C}$-labelled phenols could help to reveal rates of transport, transformation and loss in experimental systems in future studies. The less tangible effects are those of the litter-derived organic inputs on the soil microbial community. The biodegradability of the DOC, and therefore its effect on soil microorganisms and its potential for decomposition, depends on the biochemistry of the component molecules and their relative abundances (Kalbitz et al. 2003; Dungait et al. 2011, 2013). The leached DOC from the plant litter may have accelerated the loss of SOC by positive priming of the soil microbial biomass, i.e. supplying limiting $\mathrm{C}$ or nutrients that allowed the proliferation of the microbial community and the subsequent increased decomposition and loss of SOC (Kuzyakov 2010). Microbial activity can also modify soil physical structure (Stockmann et al. 2013) and therefore the hydrological pathways through soils altering the potential for physical transport or stabilisation of DOC.

Effect of seasonal temperature change on phenol loss from soils

The contribution of plant-derived phenols to the small amount of DOC lost from the soil lysimeters was consequently diminutive, ranging between $0.8 \pm 0.1$ (oak) and $1.7 \pm 0.3 \mu \mathrm{g} / 100 \mathrm{mg}$ OC (ash) during the 671 day incubation. Total phenol concentrations in leachates from the control treatment (i.e. no litter) tended to reduce progressively with time, unlike the DOC concentrations which correlated positively with temperature change (Fig. 2). This suggests that there are processes controlling the rate of release of dissolved phenols from SOC which are temperature independent. Lignin phenols are one of the most reactive plant-derived compounds towards soil mineral surfaces and up to $56 \%$ of sorbed lignin can be irreversibly bound to minerals where individual monomers and their conformations may have different sorption bond strengths (Hernes et al. 2013) and therefore may not display obvious seasonal temperature trends. Phenolic compounds may also have anti-microbial activity (Balasundram et al. 2006) and bind proteins including free enzymes in soils (Freeman et al. 2004; Joanisse et al. 2007), both potentially diminishing decomposition.

In contrast to the bare soil controls, patterns of total phenol losses in the grass and ash litter treatments correlated positively with soil temperature dynamics in the first year (Fig. 3). Elevated ecosystem respiration rates in summer that coincide with peak activity of the soil microbial community (e.g. Kirschbaum 2013) and the effect of temperature on increasing desorption relative to adsorption rates (Le Chatelier's principle, Conant et al. 2011) may combine to effect increased rates of DOC release. Kaiser et al. (2001) also reported increased concentrations of lignin-derived phenols in forest floor leachates in warm and moist conditions in summer and autumn conditions. However, the weaker relationship between temperature and phenol release from the buttercup and oak litter treatments suggest that additional processes contributed to the dynamics of phenol release from these litter types. The most obvious explanation is the effect of tannins on microbial activity, but our analytical approach did not allow the source of phenols to be differentiated. However, senesced oak leaves in particular are likely to contain elevated concentrations of tannins (Nierop and Filley 2007). We detected greater concentrations of S6 in oak compared to the other litter types, which could be lignin or tannin-derived and distinguishable using ${ }^{13} \mathrm{C}$-labelled TMAH (Filley et al. 2006).

\section{Conclusions}

Plant-derived polyphenolic polymers such as lignin are a major input to the terrestrial $\mathrm{C}$ cycle that might be expected to contribute substantially to losses of DOC from soils. However, we observed that the overall phenol content of 'brown' senescing litters was not large and, consequently, that losses of phenols to water were also minor. During litter decomposition, the relative proportion of the phenol content to TOC increased with 
time in all litters except buttercup, and the concentration of different phenols changed between litters, suggesting that the individual phenolic composition of leaves contributes to the control of degradation rates. Similarly, the relative abundance and type of phenols lost as DOC changed over time in different plant litters. A strong relationship between seasonal temperature change and loss of DOC from the control soil (no litter) was observed, but this was either absent or only observed in the first year when the soils were treated with plant litter. A difference in phenol dynamics in DOC between plant litter types was determined, suggesting that phenol chemistry plays a role in controlling losses to water.

Acknowledgments We thank Dan Dhanoa for his assistance with statistical analysis, Richard Whalley for advice on soil physics and lysimeter preparation, Neil Donovan for help with irrigation and Paul Donohoe for analytical instrument maintenance. We would like to thank two anonymous reviewers for their wise comments. We also acknowledge financial support from the Natural Environment Research Council (NERC). This work represents part of the BBSRC-funded programmes at Rothamsted Research on Sustainable Soil Function and Climate Change.

Open Access This article is distributed under the terms of the Creative Commons Attribution 4.0 International License (http://creativecommons.org/licenses/by/4.0/), which permits unrestricted use, distribution, and reproduction in any medium, provided you give appropriate credit to the original author(s) and the source, provide a link to the Creative Commons license, and indicate if changes were made.

\section{References}

Abbott GD, Swain EY, Muhammad AB, Allton K, Belyea LR, Laing CG, Cowie GL (2013) Effect of water-table fluctuations on the degradation of Sphagnum phenols in surficial peats. Geochimica et Cosmochimica Acta 106:177-191

Amelung W, Flach KW, Zech W (1999) Lignin in particle-size fractions of native grassland soils as influenced by climate. Soil Sci Soc Am J 63:1222-1228

Austin AT, Vivanco L, González-Arzac A, Pérez LI (2014) There's no place like home? An exploration of the mechanisms behind plant litter-decomposer affinity in terrestrial ecosystems. New Phytol. 204:307-314

Bahri H, Dignac MF, Rumpel C, Rasse DP, Chenu C, Mariotti A (2006) Lignin turnover kinetics in an agricultural soil is monomer specific. Soil Biol Biochem 38:1977-1988

Balasundram N, Sundram K, Samman S (2006) Phenolic compounds in plants and Agri-industrial by-products: antioxidant activity, occurrence, and potential uses. Food Chem 99:191203
Benner R, Kaiser K (2011) Biological and photochemical transformations of amino acids and lignin phenols in riverine dissolved organic matter. Biogeochemistry 102:209-222

Berg B, McClaugherty C (2014) Decomposer Organisms. In Plant Litter. Springer, Berlin Heidelberg, pp 35-52

Berg B, Steffen KT, McClaugherty C (2007) Litter decomposition rate is dependent on litter Mn concentrations. Biogeochemistry 82:29-39

Bol R, Bolger T, Cully R, Little D (2003) Recalcitrant soil organic materials mineralize more efficiently at higher temperatures. J Plant Nutr Soil Sci Z Pflanzenernahr Bodenkd 166:300 307

Bol R, Poirier N, Balesdent J, Gleixner G (2009) Molecular turnover time of soil organic matter in particle-size fractions of an arable soil. Rapid Commun Mass Spectrom 23:25512558

Bosatta E, Agren GI (1999) Soil organic matter quality interpreted thermodynamically. Soil Biol Biochem 31:1889-1891

Bray SR, Kitajima K, Mack MC (2012) Temporal dynamics of microbial communities on decomposing leaf litter of 10 plant species in relation to decomposition rate. Soil Biol Biochem 49:30-37

Chabbi A, Rumpel C (2004) Decomposition of plant tissue submerged in an extremely acidic mining lake sediment: phenolic $\mathrm{CuO}$-oxidation products and solid-state (13)C NMR spectroscopy. Soil Biol Biochem 36:1161-1169

Collins AL, Williams LJ, Zhang YS, Marius M, Dungait JAJ, Smallman DJ, Dixon ER, Stringfellow A, Sear DA, Jones JI, Naden PS (2013) Catchment source contributions to the sediment-bound organic matter degrading salmonid spawning gravels in a lowland river, southern England. Sci Total Environ 456:181-195

Conant RT, Steinweg JM, Haddix ML, Paul EA, Plante AF, Six J (2008) Experimental warming shows that decomposition temperature sensitivity increases with soil organic matter recalcitrance. Ecology 89:2384-2391

Conant RT, Ryan MG, Agren GI, Birge HE, Davidson EA, Eliasson PE, Evans SE, Frey SD, Giardina CP, Hopkins FM, Hyvonen R, Kirschbaum MUF, Lavallee JM, Leifeld J, Parton WJ, Steinweg JM, Wallenstein MD, Wetterstedt JAM, Bradford MA (2011) Temperature and soil organic matter decomposition rates - synthesis of current knowledge and a way forward. Glob Chang Biol 17:3392-3404

Cornwell WK, Cornelissen JHC, Amatangelo K, Dorrepaal E, Eviner VT, Godoy O, Hobbie SE, Hoorens B, Kurokawa H, Pérez-Harguindeguy N, Quested HM, Santiago LS, Wardle DA, Wright IJ, Aerts R, Allison SD, Van Bodegom P, Brovkin V, Chatain A, Callaghan TV, Díaz S, Garnier E, Gurvich DE, Kazakou E, Klein JA, Read J, Reich PB, Soudzilovskaia NA, Vaieretti MV, Westoby M (2008) Plant species traits are the predominant control on litter decomposition rates within biomes worldwide. Ecol Lett 11:10651071

Davidson EA, Janssens IA (2006) Temperature sensitivity of soil carbon decomposition and feedbacks to climate change. Nature 440:165-173

Dungait JAJ, Stear NA, van Dongen BE, Bol R, Evershed RP (2008) Off-line pyrolysis and compound-specific stable carbon isotope analysis of lignin moieties: a new method for determining the fate of lignin residues in soil. Rapid Commun Mass Spectrom 22:1631-1639 
Dungait JAJ, Kemmitt SJ, Michallon L, Guo S, Wen Q, Brookes PC, Evershed RP (2011) Variable responses of the soil microbial biomass to trace concentrations of 13C-labelled glucose, using 13C-PLFA analysis. Eur J Soil Sci 62:117-126

Dungait JAJ, Hopkins DW, Gregory AS, Whitmore AP (2012) Soil organic matter turnover is governed by accessibility not recalcitrance. Glob Chang Biol 18:1781-1796

Dungait JAJ, Kemmitt SJ, Michallon L, Guo S, Wen Q, Brookes PC, Evershed RP (2013) The variable response of soil microorganisms to trace concentrations of low molecular weight organic substrates of increasing complexity. Soil Biol Biochem 64:57-64

Filley TR, Nierop KGJ, Wang Y (2006) The contribution of polyhydroxyl aromatic compounds to tetramethylammonium hydroxide lignin-based proxies. Org Geochem 37:711-727

Freeman C, Ostle NJ, Fenner N, Kang H (2004) A regulatory role for phenol oxidase during decomposition in peatlands. Soil Biol Biochem 36:1663-1667

Grandy AS, Neff JC (2008) Molecular C dynamics downstream: the biochemical decomposition sequence and its impact on soil organic matter structure and function. Sci Total Environ 404:297-307

Hartley IP, Ineson P (2008) Substrate quality and the temperature sensitivity of soil organic matter decomposition. Soil Biol Biochem 40:1567-1574

Hattenschwiler S, Gasser P (2005) Soil animals alter plant litter diversity effects on decomposition. Proc Natl Acad Sci U S A 102:1519-1524

Hernes PJ, Robinson AC, Aufdenkampe AK (2007) Fractionation of lignin during leaching and sorption and implications for organic matter "freshness". Geophys Res Lett 34:L17401

Hernes PJ, Kaiser K, Dyda RY, Cerli C (2013) Molecular trickery in soil organic matter: hidden lignin. Environ Sci Technol. 47:9077-9085

Joanisse GD, Bradley RL, Preston CM, Munson AD (2007) Soil enzyme inhibition by condensed litter tannins may drive ecosystem structure and processes: the case of Kalmia angustifolia. New Phytol. 175:535-546

Kahl T, Mund M, Bauhus J, Schulze E-D (2012) Dissolved organic carbon from European beech logs: patterns of input to and retention by surface soil. Ecoscience 19:364-373

Kaiser K, Kalbitz K (2012) Cycling downwards - dissolved organic matter in soils. Soil Biol Biochem 52:29-32

Kaiser K, Guggenberger G, Haumaier L, Zech W (2001) Seasonal variations in the chemical composition of dissolved organic matter in organic forest floor layer leachates of old-growth Scots pine (Pinus sylvestris L.) and European beech (Fagus sylvatica L.) stands in northeastern Bavaria, Germany. Biogeochemistry 55:103-143

Kalbitz K, Solinger S, Park JH, Michalzik B, Matzner E (2000) Controls on the dynamics of dissolved organic matter in soils: a review. Soil Sci 165:277-304

Kalbitz K, Schwesig D, Schmerwitz J, Kaiser K, Haumaier L, Glaser B, Ellerbrock R, Leinweber P (2003) Changes in properties of soil-derived dissolved organic matter induced by biodegradation. Soil Biol Biochem 35:1129-1142

Kalbitz K, Meyer A, Yang R, Gerstberger P (2007) Response of dissolved organic matter in the forest floor to long-term manipulation of litter and throughfall inputs. Biogeochemistry 86:301-318
Karhu K, Auffret MD, Dungait JAJ, Hopkins DW, Prosser JI, Singh BK, Subke J-A, Wookey PA, Agren GI, Sebastia MT, Gouriveau F, Bergkvist G, Meir P, Nottingham AT, Salinas N, Hartley IP (2014) Temperature sensitivity of soil respiration rates enhanced by microbial community response. Nature 513:81-84

Kemmitt SJ, Lanyon CV, Waite IS, Wen Q, Addiscott TM, Bird NRA, O'Donnell AG, Brookes PC (2008) Mineralization of native soil organic matter is not regulated by the size, activity or composition of the soil microbial biomass - a new perspective. Soil Biol Biochem 40:61-73

Kirschbaum MUF (2013) Seasonal variations in the availability of labile substrate confound the temperature dependence of organic matter decomposition. Soil Biol Biochem 57:568576

Klotzbücher T, Filley TR, Kaiser K, Kalbitz K (2011a) A study of lignin degradation in leaf and needle litter using 13C-labelled tetramethylammonium hydroxide (TMAH) thermochemolysis: Comparison with $\mathrm{CuO}$ oxidation and van Soest methods. Org Geochem 42:1271-1278

Klotzbücher T, Kaiser K, Guggenberger G, Gatzek C, Kalbitz K (2011b) A new conceptual model for the fate of lignin in decomposing plant litter. Ecology 92:1052-1062

Knicker H (2011) Soil organic N-An under-rated player for C sequestration in soils? Soil Biol Biochem. 43:1118-1129

Kraus TC, Dahlgren R, Zasoski R (2003) Tannins in nutrient dynamics of forest ecosystems - a review. Plant Soil 256: $41-66$

Kuzyakov Y (2010) Priming effects: interactions between living and dead organic matter. Soil Biol Biochem 42:1363-1371

Lal R (2004) Soil carbon sequestration impacts on global climate change and food security. Science 304:1623-1627

LandIS (2015) Cranfield University 2015. The Soils Guide. Available: www.landis.org.uk. Cranfield University, UK

Liski J, Ilvesniemi H, Makela A, Westman CJ (1999) $\mathrm{CO}_{2}$ emissions from soil in response to climatic warming are overestimated - the decomposition of old soil organic matter is tolerant of temperature. Ambio 28:171-174

Lloyd CEM, Michaelides K, Chadwick DR, Dungait JAJ, Evershed RP (2012) Tracing the flow-driven vertical transport of livestock-derived organic matter through soil using biomarkers. Org Geochem 43:56-66

Lorenz K, Lal R, Preston CM, Nierop KGJ (2007) Strengthening the soil organic carbon pool by increasing contributions from recalcitrant aliphatic bio(macro)molecules. Geoderma 142: $1-10$

Louchouarn P, Opsahl S, Benner R (2000) Isolation and quantification of dissolved lignin from natural waters using solidphase extraction and GC/MS. Anal Chem 72:2780-2787

Marschner B, Bredow A (2002) Temperature effects on release and ecologically relevant properties of dissolved organic carbon in sterilised and biologically active soil samples. Soil Biol Biochem 34:459-466

Mary B, Recous S, Darwis D, Robin D (1996) Interactions between decomposition of plant residues and nitrogen cycling in soil. Plant Soil 181:71-82

Melillo JM, Aber JD, Muratore JF (1982) Nitrogen and lignin control of hardwood leaf litter decomposition dynamics. Ecology 63:621-626

Nierop KGJ, Filley TR (2007) Assessment of lignin and (poly)phenol transformations in oak (Quercus robur) dominated 
soils by ${ }^{13} \mathrm{C}$-TMAH thermochemolysis. Org Geochem 38 : $551-565$

Paterson E (2009) Comments on the regulatory gate hypothesis and implications for C-cycling in soil. Soil Biol Biochem 41: 1352-1354

Peukert S, Griffith BA, Murray PJ, Macleod CJA, Brazier RE (2014) Intensive management in grasslands causes diffuse water pollution at the farm scale. J Environ Qual 43:20092023

Pisani O, Frey SD, Simpson AJ, Simpson MJ (2015) Soil warming and nitrogen deposition alter soil organic matter composition at the molecular-level. Biogeochemistry 123:391-409

Placella SA, Brodie EL, Firestone MK (2012) Rainfall-induced carbon dioxide pulses result from sequential resuscitation of phylogenetically clustered microbial groups. Proc Natl Acad Sci U S A 109:10931-10936

Riutta T, Slade EM, Bebber DP, Taylor ME, Malhi Y, Riordan P, Macdonald DW, Morecroft MD (2012) Experimental evidence for the interacting effects of forest edge, moisture and soil macrofauna on leaf litter decomposition. Soil Biol Biochem 49:124-131

Robertson SA, Mason SL, Hack E, Abbott GD (2008) A comparison of lignin oxidation, enzymatic activity and fungal growth during white-rot decay of wheat straw. Org Geochem 39:945-951

Sanaullah M, Chabbi A, Lemaire G, Charrier X, Rumpel C (2010) How does plant leaf senescence of grassland species influence decomposition kinetics and litter compounds dynamics? Nutr Cycl Agroecosyst 88:159-171

Sanaullah M, Rumpel C, Charrier X, Chabbi A (2012) How does drought stress influence the decomposition of plant litter with contrasting quality in a grassland ecosystem? Plant Soil 352: 277-288

Scheibe A, Gleixner G (2014) Influence of litter diversity on dissolved organic matter release and soil carbon formation in a mixed beech forest. PLoS One 9:e114040

Schmidt MWI, Torn MS, Abiven S, Dittmar T, Guggenberger G, Janssens IA, Kleber M, Kögel-Knabner I, Lehmann J, Manning DAC, Nannipieri P, Rasse DP, Weiner S, Trumbore SE (2011) Persistence of soil organic matter as an ecosystem property. Nature 478:49-56

Stockmann U, Adams MA, Crawford JW, Field DJ, Henakaarchchi N, Jenkins M, Minasny B, McBratney AB, Courcelles VR, Singh K, Wheeler I, Abbott L, Angers DA, Baldock J, Bird M, Brookes PC, Chenu C, Jastrow JD, Lal R, Lehmann J, O'Donnell AG, Parton WJ, Whitehead D, Zimmermann M (2013) The knowns, known unknowns and unknowns of sequestration of soil organic carbon. Agric Ecosyst Environ 164:80-99

Thevenot M, Dignac M-F, Rumpel C (2010) Fate of lignins in soils: a review. Soil Biol Biochem 42:1200-1211

Tipping E, Chamberlain PM, Fröberg M, Hanson PJ, Jardine PM (2012) Simulation of carbon cycling, including dissolved organic carbon transport, in forest soil locally enriched with ${ }^{14} \mathrm{C}$. Biogeochemistry 108:91-107

Toosi ER, Doane TA, Horwath WR (2012) Abiotic solubilization of soil organic matter, a less-seen aspect of dissolved organic matter production. Soil Biol Biochem 50:12-21

Toosi ER, Schmidt JP, Castellano MJ (2014) Soil temperature is an important regulatory control on dissolved organic carbon supply and uptake of soil solution nitrate. Eur J Soil Biol 61:68-71

Vane CH (2003) The molecular composition of lignin in spruce decayed by white-rot fungi (Phanerochaete chrysosporium and Trametes versicolor) using pyrolysis-GC-MS and thermochemolysis with tetramethylammonium hydroxide. Int Biodeterior Biodegrad 51:67-75

Vane CH, Abbott GD, Head IM (2001a) The effect of fungal decay (Agaricus bisporus) on wheat straw lignin using pyrolysisGC-MS in the presence of tetramethylammonium hydroxide (TMAH). J Anal Appl Pyrolysis 60:69-78

Vane CH, Martin SC, Snape CE, Abbott GD (2001b) Degradation of lignin in wheat straw during growth of the oyster mushroom (Pleurotus ostreatus) using off-line thermochemolysis with tetramethylammonium hydroxide and solid-state ${ }^{13} \mathrm{C}$ NMR. J Agric Food Chem 49:2709-2716

Waldrop MP, Firestone MK (2004) Altered utilization patterns of young and old soil $\mathrm{C}$ by microorganisms caused by temperature shifts and N additions. Biogeochemistry 67:235-248

Walela C, Daniel H, Wilson B, Lockwood P, Cowie A, Harden S (2014) The initial lignin:6nitrogen ratio of litter from above and below ground sources strongly and negatively influenced decay rates of slowly decomposing litter carbon pools. Soil Biol Biochem 77:268-275

Worrall F, Burt T, Shedden R (2003) Long term records of riverine dissolved organic matter. Biogeochemistry 64:165-178

Zeller B, Colin-Belgrand M, Dambrine E, Martin F, Bottner P (2000) Decomposition of ${ }^{15} \mathrm{~N}$-labelled beech litter and fate of nitrogen derived from litter in a beech forest. Oecologia 123: $550-559$

Zhang J, Loynachan TE, Raich JW (2011) Artificial soils to assess temperature sensitivity of the decomposition of model organic compounds: effects of chemical recalcitrance and claymineral composition. Eur J Soil Sci 62:863-873 